\title{
SPINNING AND WEAVING OF THE MIDDLE DON POPULATION OF THE SCYTHIAN TIME ${ }^{1}$
}

\author{
Aleksandr N. Merkulov \\ Voronezh State Pedagogical University, Voronezh, Russian Federation \\ Marina M. Savenkova \\ Voronezh State Pedagogical University, Voronezh, Russian Federation
}

\begin{abstract}
Introduction. The article analyzes the level of developing spinning and weaving production of the Middle Don population in the Scythian time. Based on studying textile prints on the bottoms of ceramic vessels, as well as some extant samples of fabrics, the fineness of threads and the direction of their twist, the type of weave and the density of fabrics are reconstructed. Methods. The authors studied 18 samples of fabric imprints on the bottoms of the ceramic vessels of Mostyshche hillfort. The imprints were made with the help of highly plastic clay. The analysis of the extant fragments of fabrics was carried out with the help of microscopic equipment in the laboratory of the State Historical Museum. Analysis. The fabric imprints of different varieties made of fibers of vegetable origin were found on the pottery from Mostishche hillfort. The density of coarser ones did not exceed 10 threads per $1 \mathrm{~cm}$. The majority were fabrics with a density of up to 15 threads per $1 \mathrm{~cm}$. The textile from the barrow burials was made of woolen threads, was of high density and, accordingly, a higher quality. In addition, one of the fabric fragments found in the barrows was painted red, and probably was imported. Results. Almost all analyzed samples had a simple plain weave of $1 / 1$. An exception was only a fragment of fabrics found near Mastyugino village, which had a rep weave of $1 / 3$. The fineness of threads in fabrics varied, but, as a rule, was uniform over the entire length, which indicates a highly developed spinning process. The uniform distribution of weft and warp threads in the fabric structure, as well as using threads of different twist direction in one fabrics, shows developed weaving production. The analysis of other archaeological sources, as well as involving ethnographic data allows the authors of the article to assume parallel use of horizontal and vertical weaving looms in the Scythian time in the Middle Don.
\end{abstract}

Key words: Middle Don, Scythian time, spinning, weaving, economy.

Citation. Merkulov A.N., Savenkova M.M. Spinning and Weaving of the Middle Don Population of the Scythian Time. Vestnik Volgogradskogo gosudarstvennogo universiteta. Seriya 4. Istoriya. Regionovedenie. Mezhdunarodnye otnosheniya [Science Journal of Volgograd State University. History. Area Studies. International Relations], 2019, vol. 24, no. 3, pp. 37-46. (in Russian). DOI: https://doi.org/10.15688/jvolsu4.2019.3.3

Дата поступления статьи: 05.03.2018

\section{ПРЯДЕНИЕ И ТКАЧЕСТВО У СРЕДНЕДОНСКОГО НАСЕЛЕНИЯ СКИФСКОГО ВРЕМЕНИ ${ }^{1}$}

\section{Александр Николаевич Меркулов}

Воронежский государственный педагогический университет, г. Воронеж, Российская Федерация

\section{Марина Михайловна Савенкова}

Воронежский государственный педагогический университет, г. Воронеж, Российская Федерация

Аннотация. В статье анализируется уровень развития прядильного и ткацкого производства у среднедонского населения скифского времени. На основе исследования отпечатков текстиля на днищах керамичес- 
ких сосудов, а также некоторых сохранившихся образцов материи реконструируются тонина нитей и направление их крутки, вид переплетения и плотность тканей. Авторами исследовано 18 образцов отпечатков тканей с днищ лепных сосудов городища Мостище. Снятие негативов производилось при помощи высокопластичной глины. Анализ сохранившихся фрагментов материи проводился с помощью микроскопического оборудования в лаборатории Государственного исторического музея. На керамической посуде с городища Мостище встречены отпечатки тканей разных сортов из волокон растительного происхождения. Плотность более грубых не превышает в основе 10 нитей на 1 см. Большинство составляют ткани с густотой, доходящей до 15 нитей на 1 см в основе. Текстиль из курганных могильников изготовлен из шерстяных нитей, имеет большую плотность и, соответственно, более высокое качество. Кроме того, один из обнаруженных в курганах фрагментов ткани был окрашен в красный цвет и, вероятно, имел импортное происхождение. Практически все проанализированные образцы имели простое полотняное переплетение 1/1. Исключением стал лишь фрагмент ткани, обнаруженный в могильнике у с. Мастюгино, который имел репсовое переплетение 1/3. Тонина нитей в полотнах различалась, но, как правило, была равномерной по всей длине, что свидетельствует о высокоразвитом процессе прядения. А равномерное распределение в структуре тканей нитей утка и основы, а также использование нитей различного направления крутки в одной ткани говорят о развитом ткацком производстве. Анализ других археологических источников, а также привлечение данных этнографии позволили авторам статьи высказать предположение о параллельном использовании в скифское время на Среднем Дону горизонтального и вертикального ткацких станков.

М.М. Савенковой были сняты негативы с керамики Мостищенского городища, проведен технологический анализ полученных отпечатков тканей, выполнена реконструкция горизонтального ткацкого станка. А.Н. Меркуловым отобран материал для исследований, проведен сравнительный анализ полученных данных с материалами других регионов Лесостепной Скифии, подготовлен основной текст рукописи и иллюстрации.

Ключевые слова: Средний Дон, скифское время, прядение, ткачество, хозяйство.

Цитирование. Меркулов А. Н., Савенкова М. М. Прядение и ткачество у среднедонского населения скифского времени // Вестник Волгоградского государственного университета. Серия 4, История. Регионоведение. Международные отношения. - 2019. - Т. 24, № 3. - С. 37-46. - DOI: https://doi.org/10.15688/ jvolsu4.2019.3.3

Введение. В скифское время прядение и ткачество играли существенную роль в экономике лесостепных земледельческих племен Днепро-Донского междуречья, однако долгое время эти домашние ремесла не подвергались целенаправленному исследованию. И если к настоящему моменту благодаря работам целого ряда специалистов $[12 ; 15 ; 16]$ для территории Лесостепной Украины эта ситуация изменилась, то материалы Среднего Дона специальному анализу подвергались всего лишь однажды $[11$, с. 69-73]. Но и тогда не были рассмотрены важнейшие вопросы, характеризующие данные отрасли хозяйства. Автор работы, А.И. Пузикова, как и большинство археологов, остановилась на констатации факта существования у среднедонских племен прядения и ткачества. Не были описаны ни структура тканей, ни технология их создания, ни используемое сырье. Причиной тому, в первую очередь, стала недостаточная источниковая база. Дальнейшие полевые исследования способствовали ее расширению, в результате чего, помимо орудий труда, используемых при производстве нитей и тканей, появляются и фрагменты самой материи, а также ее отпечатки на керамических сосудах. Целью данной работы является анализ уровня развития ткацкого производства у среднедонского населения скифской эпохи.

Методы. Древние ткани в большинстве случаев сохраняются очень плохо или вовсе не доживают до нашего времени. Однако некоторые образцы материи все же изредка встречаются в среднедонских курганах, а также доходят до нас в виде отпечатков на днищах лепной посуды, происходящей со среднедонских поселений. В работе использовано 18 образцов, полученных в виде слепков с днищ лепных сосудов городища Мостище, а также два фрагмента ткани, встреченных в кургане 32/32 могильника Мастюгино и в кургане 14 некрополя Колбино I.

Снятие негативов производилось одним из авторов статьи, М.М. Савенковой, при помощи обладающей хорошей вязкостью глины для лепки, благодаря своей пластичности передающей мельчайшие неровности поверхности сосудов; дальнейшее изучение отпечатков происходило под увеличительным стеклом. 
Анализ сохранившегося фрагмента материи из кургана 32/32 был выполнен Б.А. Шрамко [15, с. 643]. Образец ткани из кургана 14 могильника Колбино I исследован сотрудниками Отдела научной реставрации Государственного исторического музея О.Б. Лантратовой и Н.А. Счастливой [3, с. 152-161]. Данный фрагмент после его отделения и очистки изучался при помощи микроскопа МБС-9 при увеличения $2-100 x$, а также рудного микроскопа «Полам Р-312» в отраженном поляризованном свете при увеличениях 20-400x. Исследование волокон на предмет их природы и наличия в них красителя осуществлялось с помощью микроскопа «Полам Р-211» при увеличении 400x, а также по микрохимическим и гистохимическим реакциям на протеины и целлюлозу [3, с. 154-155].

Анализ. При технологическом анализе нами учитывались следующие характеристики тканей: вид переплетения, плотность нитей по основе и утку, расстояние между нитями утка и основы, наличие и тип крутки нитей, тонина нитей основы и утка.

Вид переплетения в ткани характеризует взаиморасположение нитей относительно друг друга. Было установлено, что все ткани с городища Мостище имели простейший вид переплетения нитей в ткани - 1/1 полотняное, которое характеризуется наименьшим количеством нитей утка и основы, соединенных в раппорте. Так как кромки не сохранилось и установить направление нитей основы и утка в ткани не представляется возможным, было принято общее правило, определенное А. Нахликом [9, с. 247] для средневековых тканей, которое нарушалось очень редко: нить основы тоньше и сильнее скручена, чем нить утка.

В пяти экземплярах удалось установить тип крутки нитей. При определении пряжи использованы общепринятые обозначениями $\mathrm{Z}$ и $S$, указывающими на направление крутки (Z крутка правая, $S$ крутка левая). Традиционно наиболее древней считается Z-крутка (по солнцу). Вторичное кручение пряжи идет в направлении, противоположном первичному. Ткани, оттиски которых были изучены, в основе и утке имели как однонаправленное, так и разнонаправленное скручивание. А. Нахлик установил закономерность для новгородских тканей, основывающуюся на взаимозависи- мости между самой примитивной группой тканей и простейшей комбинацией однонаправленных скручиваний [9, с. 248]. Изделия, имеющие различное направление скручивания основы и утка, свидетельствуют о более высоком уровне развития ткацкого ремесла. Он отметил, что основа и уток в льняных тканях с полотняным переплетением всегда скручены одинаково ZZ.

Плотностью называется число нитей основы и утка, приходящихся на 1 см ткани. На основании плотности определяется сорт ткани. При определении сорта были приняты показатели, установленные А. Нахликом для средневековых тканей из Новгорода [9, с. 228].

По отпечаткам на керамических сосудах можно выделить 2 группы тканей по плотности. Восемь из 18 тканей относятся к 4-му сорту, плотность которых не превышает в основе 10 нитей на 1 см и 8 на 1 см в утке; 10 образцов - к 3-му сорту ткани с плотностью, доходящей до 15 нитей на 1 см в основе и 12 нитей на 1 см в утке.

Ткани 3-го сорта. Из 18 находок больше половины (10 экз.) составляют ткани, плотность которых превышает $10 \times 10$ нитей. Один экземпляр (табл. 1,4 ), имеющий плотность $14 \times 11$ нитей, приближается вплотную ко 2-му сорту (рис. 1, 2). Тонина нитей основы и утка отличается незначительно: в основе составляет 0,3-0,5 мм, в утке-0,4-0,6 мм. Нити имеют равномерную тонину по всей длине, что говорит высокоразвитом процессе прядения нитей. Нити основы и утка равномерно распределены в структуре ткани, там, где она определяется, имеют крутку ZZ, ZS. Использование нитей различного направления крутки в одной ткани говорит о развитом процессе ткачества.

Ткани 4-го сорта. 8 экземпляров представляют собой ткани, плотность которых составляет 5-10 нитей на 1 см в основе, 6-10 нитей на 1 см в утке. Один экземпляр можно охарактеризовать как грубую ткань типа рогожи с плотностью $5 \times 6$ нитей на 1 см (рис. 1,1 ). Нити, использовавшиеся для изготовления тканей 4-го сорта, мягче, чем в 3-м сорте, расстояние между нитями равно или меньше тонины нитей. Тонина нитей в основе составляет $0,4-0,8$ мм, в утке - $0,5-1$ мм. Нити основы и утка имеют неравномерную толщину, ко- 
торая колеблется в пределах нескольких десятых мм: 0,5-0,8; 0,8-1. По сравнению с 3-м сортом ткани имеют неравномерное распределение нитей. На основании проведенного анализа можно сделать вывод о том, что в тканях 4-го сорта употребляли нити большей толщины, чем в тканях лучшего качества.

Ткань № 2 (см. таблицу) подверглась механическому воздействию. Нити основы неравномерной тонины, изгибаются в структуре ткани, расстояние между нитями неодинаковое.

Ткани обладают средней плотностью, так как расстояние между нитями во всех экземплярах приблизительно равно их толщине. Пять образцов уравновешенные по плотности, густота по основе и утку равна $10 \times 10$ нитей. Остальные неуравновешенные - плотность по основе больше, чем по утку, на 1-2 нити.

Все оттиски оставлены обычными тканями с открытой гладкой поверхностью, не обнаруживающей следов сваливания. Вероятнее всего, ткани изготавливались из волокон растительного происхождения, о чем говорят четкие отпечатки на глине, оставленные жесткими нитями. Шерстяные же нити более мягкие и упругие и должны оставлять менее четкие, смазанные следы.

Фрагмент шерстяной ткани был найден в бронзовом котле кургана 14 могильника Колбино I [3, с. 42]. Ткань имела полотняное переплетение $1 / 1$. Крутка нитей утка и основы ZZ. Тонина отличается незначительно - по свидетельству авторов анализа, в основе она составляет $0,18-0,35$ мм, в утке 0,15-0,2 мм. Однако такое соотношение нитей утка и основы вызывает вопрос. Обычно нить основы тоньше нити утка, поскольку для нее используется сильно скрученная нить, подвергающаяся большему натяжению. В данном случае кромок ткани не сохранилось, и направление нитей основы и угка было определено произвольно. Густота нитей основы составляла 1520/1 см, утка 20-30/1 см, что позволяет отнести данную ткань к первому сорту по классификации А. Нахлика. Кроме того, удалось установить, что полотно было окрашено в красный цвет, причем покраска шерсти проводилась на стадии волокнистого сырья, а не ткани или нити, что дает самые качественные результаты окрашивания [3, с. 152-161]. Высокое качество материи, а также совершенная технология окрашивания может свидетельствовать о ее дороговизне и возможном импортном происхождении.

В кургане 32/32 у с. Мастюгино встречен фрагмент шерстяной ткани с репсовым переплетением $1 / 3$, анализ которой произведен Б.А. Шрамко [15, с. 643]. Остатки ткани сохранились на втулке копья. Нити основы в шахматном порядке перекрываются тремя нитями утка. Достоверно направление кручения установить не удалось, однако в некоторых случаях у проводивших анализ специалистов сложилось впечатление о левой крутке. Плотность ткани по основе 7/1 см, по утку 1720/1 см. Данная ткань относится ко 2-му сорту.

Результаты. Проведенные исследования показывают, что в качестве сырья для изготовления тканей на Среднем Дону использовались как растительные волокна, так и шерсть. Растительные ткани могли производиться из конопли, крапивы, льна. Для среднедонского населения к настоящему моменту отсутствуют источники, способные подтвердить или опровергнуть использование волокон какого-либо из этих растений для производства тканей. В материалах же Поднепровья имеются достоверные свидетельства использования льняных материй, а для создания шерстяных нитей там применялась овечья шерсть [15, с. 600, 614-615]. Вероятно, шерсть мелкого рогатого скота, в том числе и овец, использовалась для этих целей и на Среднем Дону. В составе стада местных племен МРС занимает третье место после лошади и крупного рогатого скота, достигая иногда в репрезентативных выборках пятой части от общего количества домашних животных $[1 ; 17 ; 18]$. По аналогии с материалами Левобережной Украины этого должно быть вполне достаточно для использования овец и коз в качестве источника шерсти [16, с. 128].

Получали шерсть несколькими способами: вычесывали, собирали после линьки, состригали с живых или убитых животных. Для вычесывания шерсти применялись гребни. В лесостепном Подонье имеется лишь одна находка такого рода, происходящая с Мостищенского городища [4, с. 182]. Нечасто встречаются гребни и на памятниках днепровского левобережья [15, с. 604]. Помимо вычесывания шерсти, гребни применялись и для ее 
расчесывания при подготовке к прядению. Любопытно, что именно этот прием обработки шерсти, а не ее битье, был зафиксирован Б.А. Шрамко на серии образцов тканей из памятников лесостепного Поднепровья. Об этом свидетельствует расположение волокон. В пряже из битой шерсти они размещаются хаотично, а из чесаной параллельно друг другу [15, с. 608].

Из всех обозначенных способов получения шерсти наиболее эффективным является стрижка. Первая стрижка овцы давала 1-2 кг шерсти [2, с. 106], в то время как на одного человека тратилось в среднем 0,5 кг пряжи на год $[16$, с. 128$]$. С учетом того, что овец обычно стригут несколько раз в год, настриг с одного животного вполне мог обеспечить пряжей нескольких членов семьи.

Анализ образцов археологического текстиля и оттисков тканей с керамических сосудов позволяет определить набор возможных ткацких устройств для их изготовления. Ключевым признаком для определения ткацкого устройства является разновидность приспособления для создания ткацкого зева. Отсутствие ошибок в переплетении указывает на механическое образование зева при помощи ремизки; видимо, в станке присутствовало разделение нитей на четные и нечетные с постоянным ткацким зевом.

Для изготовления тканей с полотняным переплетением на примитивном горизонтальном ткацком станке без подножек достаточно одной петельковой полуниченки и доски, отделяющей четные нити от нечетных.

На отпечатке № 9 (рис. 1, 3) представлен край ткани, на котором четко прослеживается разреженность нитей утка, увеличивающаяся к концу изделия. Эта особенность строения может указывать на отсутствие набивного механизма типа берда. В этом случае для плотной набивки нитей могли использоваться деревянные ножи, костяные гребни.

Неравномерное распределение нитей в структуре ткани указывает на работу на станке без берда или другого нитеразделителя. Однако необходимо учитывать и то, что для технических нужд могли использоваться ткани, обладающие не самым лучшим качеством.

Среди всей массы археологических керамических материалов скифского времени выделяются находки грузиков-пряслиц, часть из которых, вероятно, не использовалась в качестве маховиков для веретен, а входила в конструкцию горизонтальных ткацких станков. Об этом свидетельствуют потертости от нитей внутри каналов некоторых находок. К тому же эти предметы имеют достаточно узкие (3 мм) каналы, которые вряд ли позволяли надеть их на веретено [8, с. 19-20]. Такая ситуация характерна не только для среднедонских памятников, но и отмечена рядом исследователей на материалах других регионов [7, c. $116-122 ; 10$, с. $93 ; 16$, с. 59].

По мнению И.Л. Черная, грузики служили для натяжения нитей основы и для перемены нитей четных и нечетных, то есть смены зева. Грузик в горизонтальном ткацком станке применялся для оттягивания одной нити, что подтверждено экспериментально.

По информации исследователей, занимающихся реконструкцией текстильных приспособлений, вес грузиков для тонких нитей равен приблизительно 12-20 г, для толстых 3050 г. Для оттягивания льняных нитей требуются грузики большего веса, чем для натяжения нитей из шерсти.

При реконструкции горизонтального ткацкого станка (рис. 2) использовался метод отбора оптимальных вариантов. Так как для образования зева на вертикальном станке использовалась одна нитченка, то этот же принцип был применен в реконструкции горизонтального станка. Заправка станка могла осуществляться следующим образом. Все грузила надевались на одну нить на расстоянии, несколько превышающем размеры изготовляемого изделия, закреплялись две горизонтальные планки. Нить основы наматывалась вкруговую между планками, которые являлись естественными разделителями нитей на верхние и нижние. Одновременно происходило снование и заправка станка. Нити основы в станке делились на две группы: четные без грузов и нечетные с грузами. Под тяжестью грузов четные нити натягивались, нечетные оттягивались грузиками вниз, образуя зев. Рабочими являлась половина нитей, заправленных в грузики. К этим нитям перед грузиками навязывались нитяные петли-нитченки. Потянув за нитченку вверх, нижним нитям сообщали верхнее положение, образуя второй зев. После прокидывания утка, нитченка отпускалась, нижние нити под тя- 
жестью грузил возвращались в первоначальное положение. Верхние нити в процессе ткачества являлись пассивными, двигались нижние нити основы. Путем повтора этих действий вырабатывается текстиль простейшего полотняного переплетения. Грузики в данном устройстве являются утяжелителями для оттягивания нитей, выполняют функцию подножки.

В ходе экспериментальной работы на таком станке отмечено, что легкие грузила оттягивают нити недостаточно сильно. Это является препятствием к четкому образованию зева, так как нити из нижнего ряда попадают наверх. Чем меньше высота грузика, тем он легче и более подвижен, то есть способен к перепутыванию нитей. Возможно, вариативность форм грузил обусловливалась желанием разместить их большее количество на ограниченном участке или препятствовать сцеплению друг с другом при образовании зева. Наиболее стабильными, способствующими параллельному распределению нитей в станке являются грузила биконической и усеченно-конической формы с вытянутой осью. Усеченно-коническая форма способствует максимальному сближению нитей основы и в связи с этим более рациональному использованию их длины. Порядок расположения грузиков относительно друг друга не имеет значения. Они не выстраиваются в ряд, что невозможно осуществить практически, но могут висеть гроздью, способствуя увеличению плотности ткани.

Конструкция ткацких станков изменялась в результате поиска более эффективных способов выработки текстиля. В этнографическом материале станок с половиной движущихся нитей основы, использовавшийся у народов, ведущих кочевой образ жизни, является наиболее древним архаичным по сравнению с другими видами.

На данном этапе развития текстильного ремесла не существовало универсального ткацкого приспособления. На горизонтальном станке можно было выполнять текстильные ленты и тесьму значительной длины, но небольшой ширины. По данным этнографов, киргизы, казахи, полукочевые узбеки и другие народы Средней Азии в нач. XX века использовали примитивный горизонтальный станок с нитеразделителем в виде широкой доски для выработки тканей шириной до 20 см [14, с. 33].
Вероятно, для изготовления более широких тканей применялся вертикальный станок, который, в свою очередь, ограничивал длину материи своей высотой. Об использовании вертикальных ткацких станков населением лесостепного Поднепровья говорят не только редкие находки конических грузил, но и зафиксированные на Бельском городище остатки самого станка, реконструкцию которого произвел А.Л. Щербань. Деревянная рама станка состояла из двух вертикально забитых в землю столбов диаметром 12 см и располагавшейся на них деревянной перекладины, на которой крепились нити основы. Ширина такого устройства была $1,35 \mathrm{M}$, а расстояние между двумя крайними конусовидными грузилами, натягивающими нить основы, почти метр. Всего от этого станка обнаружено 15 грузил [16, с. 148-150].

На Среднем Дону остатков таких устройств не выявлено, однако изредка среди поселенческих материалов встречаются конусовидные и дисковидные грузила. Они найдены в материалах городищ Большое Сторожевое, Волошино I, Пекшево, Верхнее Казачье [5, табл. $13 ; 6$, рис. 50; 13$]$.

Вопрос о приоритете возникновения горизонтального или вертикального ткацкого станка до сих пор вызывает споры исследователей. На синхронных материалов Левобережной Украины А.Л. Щербань сделал вывод о том, что горизонтальный станок появляется раньше вертикального в VII - начале VI в. до н. э. Однако и после VI в. до н. э. использовались оба типа станков [16, с. 156]. По-видимому, не противоречат этому выводу и материалы Среднего Дона.

\section{ПРИМЕЧАНИЕ}

${ }^{1}$ Исследование выполнено за счет гранта Российского научного фонда (проект №17-78-20048).

Авторы выражают благодарность В.И. Гуляеву за возможность публикации результатов анализа фрагмента ткани из кургана 14 могильника Колбино I.

1 The study was supported by the Russian Science Foundation grant (project no. 17-78-20048).

The authors express their gratitude to V.I. Gulyaev for the opportunity to publish the results of the analysis of a fabric fragment from barrow 14 of Kolbino I burial ground. 
А.Н. Меркулов, М.М. Савенкова. Прядение и ткачество у среднедонского населения скифского времени

\section{ПРИЛОЖЕНИЕ}

Таблииа 1

Основные параметры тканей у среднедонского населения скифского времени

\begin{tabular}{|c|c|c|c|c|c|c|c|c|}
\hline \multirow[b]{2}{*}{$\begin{array}{l}\text { № } \\
\text { ПI/II }\end{array}$} & \multirow[b]{2}{*}{$\begin{array}{c}\text { Наи менован } \\
\text { ие } \\
\text { памятника }\end{array}$} & \multirow[b]{2}{*}{ Плотность } & \multicolumn{3}{|c|}{ Основа } & \multicolumn{3}{|c|}{ Уток } \\
\hline & & & $\begin{array}{c}\text { Тонина } \\
\text { (мм) }\end{array}$ & Крутка & $\begin{array}{c}\text { Расстояние } \\
\text { между } \\
\text { нитями (мм) }\end{array}$ & Тонина (мм) & Крутка & $\begin{array}{c}\text { Расстояние } \\
\text { между нитями } \\
\text { (мм) }\end{array}$ \\
\hline 1 & Мостище & $5 \times 6$ & $0,5-0,8$ & S? & $0,5-0,7$ & $0,8-1$ & Z & $0,8-1$ \\
\hline 2 & Мостище & $8 \times 6$ & $0,7-0,8$ & $Z$ & $0,5-0,7$ & 0,8 & $\mathrm{Z}$ & $0,5-0,6$ \\
\hline 3 & Мостище & $9-10 \times 9-8$ & 0,5 & $\mathrm{~S}$ & $0,5-0,7$ & $0,7-0,8$ & $\mathrm{Z}$ & $0,5-1$ \\
\hline 4 & Мостище & $14 \times 11$ & $0,4-0,5$ & $\mathrm{Z}$ & $0,5-0,3$ & $0,6-0,5$ & $\mathrm{Z}$ & $0,5-0,6$ \\
\hline 5 & Мостище & $11 \times 12$ & 0,3 & не опред. & $0,2-0,5$ & 0,4 & $\mathrm{Z}$ & 0,3 \\
\hline 6 & Мостище & $9 \times 9$ & 0,5 & не опред. & 0,5 & 0,5 & не опред. & $0,3-0,2$ \\
\hline 7 & Мостище & $9 \times 8$ & $0,4-0,5$ & $\mathrm{Z}$ & $0,5-0,7$ & $0,7-0,8$ & Z & $0,5-0,7$ \\
\hline 8 & Мостище & $12 \times 7$ & 0,5 & Z & 0,5 & 0,8 & $\mathrm{~S}$ & 0,8 \\
\hline 9 & Мостище & $10 \times 8$ & 0,5 & $Z$ & 0,5 & 0,5 & не опред. & 0,5 \\
\hline 10 & Мостище & $12 \times 11$ & $0,4-0,5$ & не опред. & $0,3-0,5$ & 0,4 & не опред. & $0,3-0,5$ \\
\hline 11 & Мостище & $10 \times 10$ & 0,5 & $\mathrm{Z}$ & $0,3-0,5$ & $0,5-0,8$ & $\mathrm{~S} ?$ & 0,5 \\
\hline 12 & Мостище & $10 \times 10$ & 0,5 & не опред. & $0,2-0,3$ & 0,5 & не опред. & $0,2-0,3$ \\
\hline 13 & Мостище & $7 \times 6$ & 0,7 & не опред. & $0,8-1$ & 0,7 & не опред. & $0,5-0,7$ \\
\hline 14 & Мостище & $10 \times 10$ & 0,5 & не опред. & 0,3 & 0,5 & не опред. & 0,5 \\
\hline 15 & Мостище & $10 \times 10$ & 0,5 & не опред. & $0,2-0,3$ & 0,5 & не опред. & 0,5 \\
\hline 16 & Мостище & $11 \times 12$ & 0,3 & не опред. & $0,2-0,1$ & 0,5 & не опред. & 0,5 \\
\hline 17 & Мостище & $10 \times 10$ & 0,5 & не опред. & 0,2 & 0,5 & не опред. & 0,3 \\
\hline 18 & Мостище & $8 \times 6$ & 0,8 & $\mathrm{~S} ?$ & $0,5-0,8$ & 0,8 & $\mathrm{Z}$ & $0,8-1$ \\
\hline 19 & $\begin{array}{c}\text { Мастюгино, } \\
\text { к. } 32 / 32 \\
\end{array}$ & $7 \times 17-20$ & не опред. & $\mathrm{S} ?$ & не опред. & не опред. & $\mathrm{S} ?$ & не опред. \\
\hline 20 & $\begin{array}{c}\text { Колбино I, } \\
\text { к. } 14\end{array}$ & $15-20 \times 20-30$ & $0,18-0,35 ?$ & Z & $0,08-0,65$ & $0,15-0,2$ & Z & $0,08-0,65$ \\
\hline
\end{tabular}
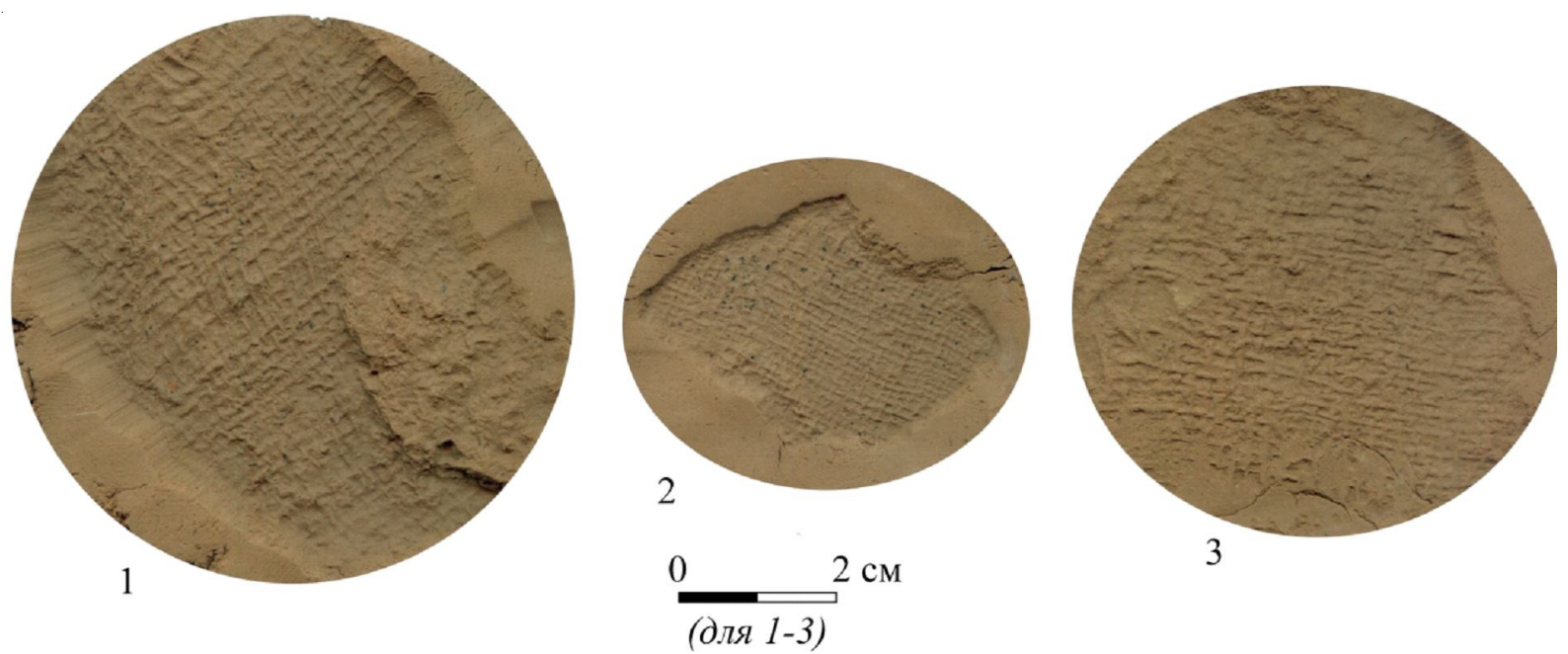

Рис. 1. Отпечатки тканей на керамических сосудах:

1 - отпечаток ткани типа «рогожи»; 2 - отпечаток ткани полотняного переплетения;

3 - отпечаток ткани с разреженными нитями утка

Fig. 1. Fabric imprints on ceramic vessels:

1 - fabric imprint of the "mats" type, 2 - plain weave fabric imprint;

3 - fabric imprint with sparse weft threads 


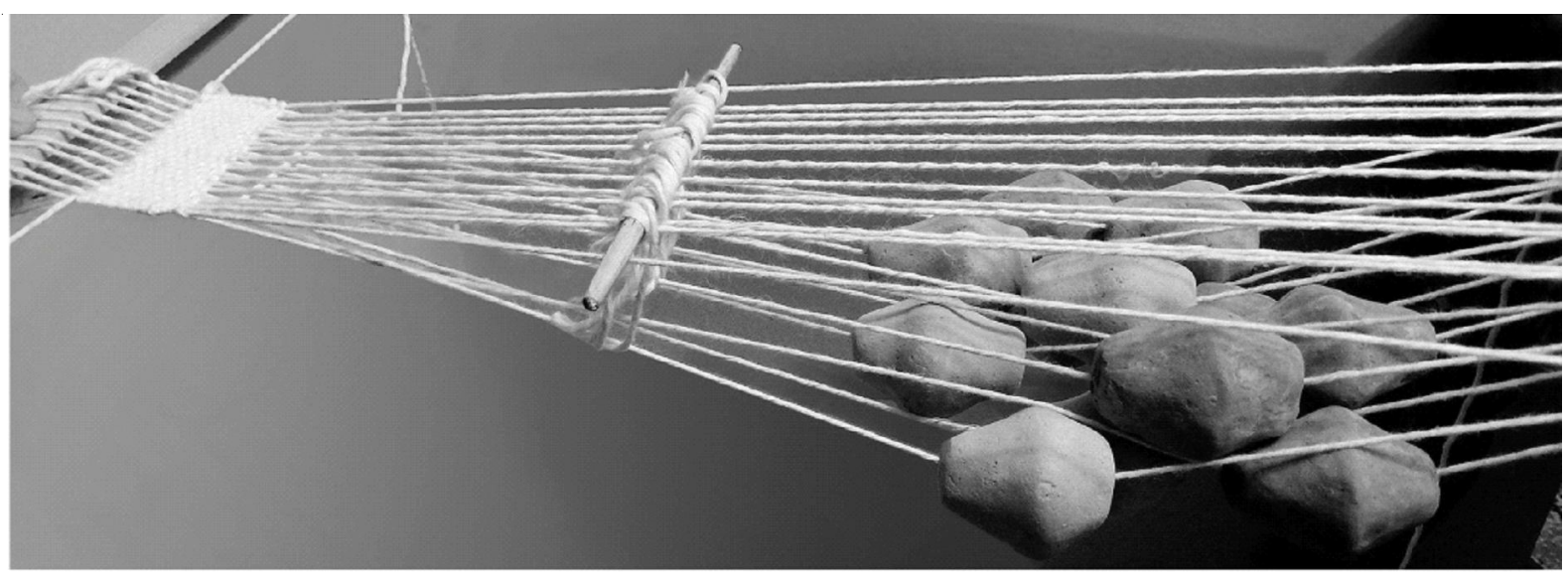

Рис. 2. Экспериментальная модель ткацкого станка

Fig. 2. Experimental model of the loom 


\section{СПИСОК ЛИТЕРАТУРЫ}

1. Антипина, Е. Е. Остеологические материалы из скифских памятников на Среднем Дону / Е. Е. Антипина // Археология Среднего Дона в скифскую эпоху : (Труды Донской (Потуданской) археологической экспедиции ИА РАН, 20012003 гг.). - М. : ИА РАН, 2004. - С. 107-118.

2. Гаврилюк, Н. А. Скотоводство Степной Скифии/Н. А. Гаврилюк.-Киев : ИАНАНУ, 1995. - 141 с.

3. Гуляев, В. И. Отчет о работе Потуданской экспедиции Института археологии РАН в 1999 году / В. И. Гуляев // Архив ИА РАН. - Р-1. - № 22709.

4. Килейников, В. В. Функциональный анализ каменных, костяных и керамических орудий труда Мостищенского городища / В. В. Килейников // Мостищенский комплекс древних памятников (эпоха бронзы - ранний железный век) / А. Т. Синюк, В. Д. Березуцкий. - Воронеж : Воронеж. госпедуниверистет, 2001.- С. 179-190.

5. Либеров, П. Д. Памятники скифского времени на Среднем Дону / П. Д. Либеров // Свод археологических источников. Вып. Д1-31. - 1965. - 111 с.

6. Медведев, А. П. Отчет скифо-сарматского отряда археологической экспедиции Воронежского госуниверситета о работах в 1987 г. / А. П. Медведев // Архив ИА РАН. - Р-1. - № 12056.

7. Мельниковская, О. Н. Племена южной Белоруссии в раннем железном веке / О. Н. Мельниковская. - М. : Наука, 1967. - 194 с.

8. Меркулов, А. Н. Глиняные грузики и пряслица с городища скифского времени у с. Пекшево на р. Воронеж / А. Н. Меркулов // История: факты и символы. - 2018. - № 1 (14). - C. 16-22. - DOI: 10.24888/2410-4205-2018-14-1-16-22.

9. Нахлик, А. Ткани Новгорода: Опыт технологического анализа / А. Нахлик // Материалы и исследования по археологии СССР. - 1963. - № 123. C. 228-313.

10. Пузикова, А. И. Марицкое городище в Посеймье / А. И. Пузикова. - М. : Наука, 1981. - 120 с.

11. Пузикова, А. И. Поселения Среднего Дона / А. И. Пузикова // Материалы и исследования по археологии СССР. - 1969. - № 151. - С. 41-95.

12. Радзієвська, В. С. Техніка прядіння у населення лісостепової Скіфії / В. С. Радзієвська // Археологія. - 1979. - Т. 32. - С. 19-26.

13. Разуваев, Ю. Д. Раскопки городищ в Верхнем Подонье / Ю. Д. Разуваев, И. А. Козмирчук // Археологические исследования в Центральном Черноземье 2015. - Липецк : Новый взгляд, 2016. C. 117-121.

14. Шишлина, Н. И. Текстиль эпохи бронзы прикаспийских степей / Н. И. Шишлина // Текстиль эпохи бронзы прикаспийских степей. - М. : ГИМ, 1999. - С. 7-38. - (Труды ГИМ ; вып. 109).
15. Шрамко, Б. А. Хозяйство лесостепных племен Восточной Европы в скифскую эпоху : дис. ... д-ра ист. наук / Шрамко Борис Андреевич. - Киев, 1965. $-421 \mathrm{c}$.

16. Щербань, А. Л. Прядіння і ткацтво у населення Лівобережного Лісостепу України VII початку III століття до н.е. (за глиняними виробами) / А. Л. Щербань. - Киев : Молодь, 2007. - 256 с.

17. Яниш, Е. Ю. Новые остеологические материалы поселений скифского времени на Верхнем и Среднем Дону / Е. Ю. Яниш, А. Н. Меркулов // История: факты и символы. - 2016. - Вып. 9 (№ 4). C. 85-92.

18. Яниш, Е. Ю. Остеологическая коллекция скифского времени с городища у хутора Мостище / Е. Ю. Яниш, А. Н. Меркулов // Известия Воронежского государственного педагогического университета. - 2015. - № 2 (267). C. 106-111.

\section{REFERENCES}

1. Antipina E.E. Osteologicheskie materialy iz skifskikh pamyatnikov na Srednem Donu [Osteological Materials from Scythian Sites in the Middle Don]. Arkheologiya Srednego Dona v skifskuyu epokhu (Trudy Donskoy (Potudanskoy) arkheologicheskoy ekspeditsii IA RAN, 2001-2003 gg.) [Archeology of the Middle Don in the Scythian Epoch (Proceedings of the Don (Potudan) Archaeological Expedition of the Institute of Archaeology of the Russian Academy of Sciences, 2001-2003)]. Moscow, IA RAN Publ., 2004, pp. 107-118.

2. Gavrilyuk N.A. Skotovodstvo Stepnoy Skifii [Cattle Breeding of Steppe Scythia]. Kiev, IA NANU, 1995. $141 \mathrm{p}$.

3. Gulyaev V.I. Otchet o rabote Potudanskoy ekspeditsii Instituta arkheologii RAN v 1999 godu [The Report on the Work of Potudan Expedition of the Institute of Archaeology of the Russian Academy of Sciences in 1999]. Arhiv IA RAN [Archive of the Institute of Archaeology of the Russian Academy of Sciences], R 1, no. 22709.

4. Kileynikov V.V. Funktsionalnyy analiz kamennykh, kostyanykh i keramicheskikh orudiy truda Mostishchenskogo gorodishcha [Functional Analysis of Stone, Bone and Ceramic Tools of Mostyshche Hillfort]. Sinyuk A.T., Berezutskiy V.D. Mostishchenskiy kompleks drevnikh pamyatnikov (epokha bronzy ranniy zheleznyy vek) [Mostishche Complex of Ancient Sites (Bronze Age - Early Iron Age)]. Voronezh, Voronezhskiy gospeduniversitet, 2001, pp. 179-190.

5. Liberov P.D. Pamyatniki skifskogo vremeni na Srednem Donu [Sites of the Scythian Time on the Middle Don]. Svod arkheologicheskikh istochnikov [Code of Archaeological Sources], 1965, iss. D1-31.111 p. 
6. Medvedev A.P. Otchet skifo-sarmatskogo otryada arkheologicheskoy ekspeditsii Voronezhskogo gosuniversiteta o rabotakh v $1987 \mathrm{~g}$. [The Report of the Scythian-Sarmatian Group of the Archaeological Expedition of Voronezh State University on the Works in 1987]. Arkhiv IA RAN [Archive of the Institute of Archaeology of the Russian Academy of Sciences], R 1.no. 12056.

7. Melnikovskaya O.N. Plemena yuzhnoy Belorussii v rannem zheleznom veke [Tribes of Southern Byelorussia in the Early Iron Age]. Moscow, Nauka Publ., 1967. 194 p.

8. Merkulov A.N. Glinyanye gruziki i pryaslitsa s gorodishcha skifskogo vremeni u s. Pekshevo na r. Voronezh [Clay Sinkers and Spindles from the Hillfort of the Scythian Time near Pekshevo Village on the Voronezh River]. Istoriya: fakty i simvoly [History: Facts and Symbols], 2018, no. 1 (14), pp. 16-22. DOI: 10.24888/2410-4205-2018-14-1-16-22.

9. Nakhlik A. Tkani Novgoroda: Opyt tekhnologicheskogo analiza [Textile of Novgorod: Experience of Technological Analysis]. Materialy $i$ issledovaniya po arkheologii SSSR [Materials and Research on the Archaeology of the USSR], 1963, no. 123, pp. 228-313.

10. Puzikova A.I. Maritskoe gorodishche v Poseyme [Maritsa Hillfort in Seim River Area]. Moscow, Nauka Publ., 1981. 120 p.

11. Puzikova A.I. Poseleniya Srednego Dona [Settlements of the Middle Don]. Materialy $i$ issledovaniya po arkheologii SSSR [Materials and Research on Archaeology of the USSR], 1969, no. 151, pp. 41-95.

12. Radziievska, V. Ye. Tekhnika pryadinnya u naselennya lisostepovoi Skifii. Arkheologiya, 1979, vol. 32, pp. 19-26.
13. Razuvaev Yu.D., Kozmirchuk I.A. Raskopki gorodishch v Verkhnem Podone [Excavations of Hillforts in the Upper Don]. Arkheologicheskie issledovaniya $v$ Tsentralnom Chernozeme 2015 [Archaeological Research in the Central Black Earth Region 2015]. Lipetsk, Novyy vzglyad Publ., 2016, pp. 117-121.

14. Shishlina N.I. Tekstil epokhi bronzy prikaspiyskikh stepey [Textiles of the Bronze Age of the Caspian Steppes]. Tekstil epokhi bronzy prikaspiyskikh stepey [Textiles of the BronzeAge of the Caspian Steppes.]. Moscow, GIM, 1999, pp. 7-38. (Trudy GIM, vyp. 109 [Works of the State Historical Museum, iss. 109]).

15. Shramko B.A. Hozyaystvo lesostepnykh plemen Vostochnoy Evropy v skifskuyu epokhu: dis. ... $d$-ra ist. nauk [The Economy of Steppe-Forest Tribes of Eastern Europe in the Scythian Time. Dr. hist. sci. diss.]. Kiev, 1965. $421 \mathrm{p}$.

16. Shcherban A.L. Pryadinnya $i$ tkatstvo $u$ naselennya Livoberezhnogo Lisostepu Ukrä̈ni VII pochatku III stolittya do n.e. (za glinyanimi virobami). Kiev, Molod Publ., 2007. 256 p.

17. Yanish E.Yu., Merkulov A.N. Novye osteologicheskie materialy poseleniy skifskogo vremeni na Verkhnem i Srednem Donu [New Osteological Materials of Scythian Settlements in the Upper and Middle Don]. Istoriya: fakty $i$ simvoly [History: Facts and Symbols], 2016, iss. 9 (no. 4), pp. 85-92.

18. Yanish E.Yu., Merkulov A.N. Osteologicheskaya kollektsiya skifskogo vremeni s gorodishcha u khutora Mostishche [Osteological Collection of the Scythian Time from the Hillfort near Mostyshche Khutor]. Izvestiya Voronezhskogo gosudarstvennogo pedagogicheskogo universiteta [Izvestiya Voronezh State Pedagogical University], 2015, no. 2 (267), pp. 106-111.

\section{Information about the Authors}

Aleksandr N. Merkulov, Candidate of Sciences (History), Senior Lecturer, Department of Russian History, Voronezh State Pedagogical University, Lenina St., 86, 394043 Voronezh, Russian Federation, aleksandrmerkulov@mail.ru, https://orcid.org/0000-0002-9957-3065

Marina M. Savenkova, Candidate of Sciences (Art), Associate Professor, Department of Design, Voronezh State Pedagogical University, Lenina St., 86, 394043 Voronezh, Russian Federation, savenkova-m@yandex.ru, https://orcid.org/0000-0001-8293-3266

\section{Информация об авторах}

Александр Николаевич Меркулов, кандидат исторических наук, старший преподаватель кафедры истории России, Воронежский государственный педагогический университет, ул. Ленина, 86, 394043 г. Воронеж, Российская Федерация, aleksandrmerkulov@mail.ru, https://orcid.org/0000-0002-9957-3065

Марина Михайловна Савенкова, кандидат искусствоведческих наук, доцент кафедры дизайна, Воронежский государственный педагогический университет, ул. Ленина, 86, 394043 г. Воронеж, Российская Федерация, savenkova-m@yandex.ru, https://orcid.org/0000-0001-8293-3266 